\title{
FAKTOR-FAKTOR YANG MEMPENGARUHI KEPUTUSAN MAHASISWA DALAM MEMILIH PROGRAM STUDI PADA PERGURUAN TINGGI
}

\author{
Mukhtar Galib*1, Muhammad Hidayat ${ }^{2}$ \\ ${ }^{1,}$ Sekolah Tinggi Ilmu Manajemen Lasharan Jaya Makassar \\ ${ }^{2}$ Program Pascasarjana Magister manajemen, STIE Nobel Indonesia Makassar \\ e-mail: ${ }^{1}$ mukhtargalib.stimlash@gmail.com, ${ }^{2}$ hidayat@stienobel-indonesia.ac.id,
}

\begin{abstract}
Abstrak
Penelitian ini dimaksudkan untuk mengetahui pengaruh sikap, norma, kendali dan minat terhadap keputusan mahasiswa dalam memilih program studi pada Perguruan Tinggi, penelitian ini dilaksanakan pada STIMLASH JAYA Makassar dengan mengambil 69 Mahasiswa sebagai sampel penelitian. Hasil penelitian ini membuktikan bahwa secara parsial terbukti jika sikap, norma dan minat berpengaruh terhadap keputusan mahasiswa sedangkan kendali terbukti tidak berpengaruh terhadap keputusan mahasiswa. Penelitian ini juga membuktikan secara simultan sikap, norma, kendali dan minat berpengaruh terhadap keputusan mahasiswa dalam memilih program studi pada Perguruan Tinggi penelitian ini menghasilkan nilai koefisien determinasi sebesar $98,8 \%$ yang menunjukkan bahwa model penelitian ini dapat menjelaskan bahwa keputusan mahasiswa dipengaruhi sebesar $98,8 \%$ variabel penelitian ini dan sebesar $1,2 \%$ dipengaruhi oleh variabel lain yang tidak diteliti dalam penelitian ini .
\end{abstract}

Kata kunci : Sikap, Norma, Kendali, Minat, Keputusan

\section{Abstract}

This study was intended to determine the effect of attitudes, norms, control and interest in student decisions in choosing study programs at Higher Education, this study was conducted at STIMLASH JAYA Makassar by taking 69 students as research samples. The results of this study prove that partially proven if attitudes, norms and interests affect student decisions while control has no effect on student decisions. This study also proves simultaneously the attitudes, norms, controls and interests influence the student's decision in choosing a study program at Higher Education. Coeficient determination of this study was $98.8 \%$ which shows that the model of this study can explain that the student's decision is influenced by $98.8 \%$ of the variables of this study and $1.2 \%$ is influenced by other variables that not examined in this study.

\section{Keywords : Attitudes, Norms, Control, Interest, decisions}

\section{PENDAHULUAN}

Perkembangan teknologi dan ilmu pengetahuan semakin membuat kepedulian dan kesadaran masyarakat tentang pentingnya Pendidikan terutama keberlanjutan pendidikannya di Perguruan Tinggi. Dan faktanya adalah Pendidikan merupakan tuntutan dalam masyarakat modern, baik dari segi politik maupun dari segi ekonomi (Hamalik, 2004). Maka dari itu, pendidikan adalah hal yang penting bagi kehidupan berbangsa dan bernegara. Terlebih keberadaan pendidikan tinggi adalah sebagai desiginer sekaligus pencetak sarjana yang akan membangun kehidupan berbangsa dan bernegara yang lebih baik dimasa mendatang. 
Menurut Wijaya (2008), dewasa ini persaingan antar perguruan tinggi semakin atraktif. Masyarakat akan semakin tidak mudah dalam menentukan pilihan terhadap suatu perguruan tinggi yang tepat begitu pula dalam pemilihan program studi pada Perguruan Tinggi yang menjadi pilihannya. Pilihan ini tergantung dari minat calon mahasiswa untuk memilih perguruan tinggi serta program studi yang ditawarkannya, yang dipengaruhi oleh banyak variabel yang mendahuluinya sehingga siswa dalam menentukan pilihannya akan tepat dan sesuai dengan harapan.

Pemilihan perguruan tinggi tidak lepas dari pemilihan program studi pada perguruan tinggi tersebut. Program studi yang dipilih siswa akan menentukan perguruan tinggi yang dipilih karena pemilihan program studi berkaitan dengan pencapaian cita cita atau masa depan. Dalam memilih program studi, banyak hal yang harus dipertimbangkan siswa dan orang tua. Menurut Bawantara (2007), pertimbangan dalam memilih program studi antara lain berdasarkan minat dan bakat, disesuaikan dengan kemampuan intelektual, diselaraskan dengan kemampuan finansial, dan reputasi perguruan tinggi dari program studi yang dipilih. Dengan berbagai pertimbangan tersebut, siswa diharapkan dapat memilih program studi yang sesuai dengan kondisinya demi kelancaran perkuliahan dan masa depan.

Banyak faktor yang dapat mempengaruhi perilaku seseorang termasuk mempengaruhi minat seseorang yang menjadi faktor penting dalam memutuskan untuk melakukan atau tidak melakukan sesuatu diantara teori yang mengupas hal tersebut adalah Theory of Planned Behavior (TPB) yang merupakan pengembangan lebih lanjut dari Theory Reaction Action (TRA) yang pertama kali dicetuskan oleh Ajzen pada tahun 1980 (Jogiyanto, 2007). Dalam Theory Reaction Action (TRA), Ajzen (1980) menyatakan bahwa seseorang dapat melakukan atau tidak melakukan suatu perilaku tertentu tergantung daripada minat (intensi) yang dimiliki oleh seseorang tersebut. Selanjutnya, Ajzen (1980) juga mengemukakan bahwa minat (intensi) melakukan atau tidak melakukan perilaku tertentu tersebut dipengaruhi oleh dua faktor penentu dasar, yang pertama berhubungan dengan sikap (attitude towards behavior) dan yang kedua berhubungan dengan pengaruh sosial yaitu norma subjektif (subjective norms).

Dalam Theory of Planned Behavior (TPB), Ajzen (1988) menambahkan konstruk yang belum ada dalam Theory Reaction Action (TRA), yaitu persepsi pengendalian perilaku (perceived behavioral control). Konstruk tersbut ditambahkan bertujuan untuk emahami keterbatasan yang dimiliki seorang individu dalam rangka melakukan perilaku tertentu (Chau dan $\mathrm{Hu}, 2002$ ). Dengan kata lain, dilakukan atau tidak dilakukannya suatu perilaku tidak hanya ditentukan oleh sikap dan norma subjektif saja, akan tetapi juga ditentukan oleh persepsi individu terhadap kontrol yang dapat dilakukannya yang bersumber pada keyakinannya terhadap kontrol tersebut (control beliefs).

Berdasar pada teori diatas ada empat hal penting yang dapat mempengaruhi perilaku yaitu (1) Sikap (Attitude yang didefinisikan sebagai suatu kesiapan individu untuk menanggapi dan menetapkan keyakinan atau pendapat yang merupakan pernyataan evaluatif mengenai objek atau peristiwa) Rivai dan Mulyadi (2012) (2) Norma Subjektif (Subjective norm) yaitu suatu nilai yang mendorong Seseorang memiliki keinginan terhadap suatu obyek atau perilaku seandainya ia terpengaruh oleh orang-orang di sekitarnya untuk melakukannya atau ia meyakini bahwa lingkungan atau orang-orang disekitarnya mendukung terhadap apa yang ia lakukan. Mas'ud; (2012), Michener, Delamater, dan Myers,(2004), Hartono (2007), (3)Perceived Behavioral Control (Persepsi Pengendalian Perilaku) Menurut Ajzen (2005) perilaku seseorang 


\section{AkMen}

Volume 17 Nomor 2 Juni 2020

Hal.173-182

e-ISSN : 2621-4377 \& p-ISSN : 1829-8524

Homepage: https//e-jurnal.stienobel-indonesia.acid/index.php/akmen

tidak hanya dikendalikan oleh dirinya sendiri, tetapi juga membutuhkan pengendalian atau kontrol, contohnya berupa ketersediaan sumber daya dan kesempatan bahkan keterampilan tertentu. Perceived Behavioral Control menggambarkan keyakinan seseorang tentang seberapa mudah individu melaksanakan suatu perilaku tertentu. Ketika seorang individu yakin dan percaya bahwa dirinya kekurangan sumber daya atau tidak memiliki kesempatan untuk melaksanakan suatu perilaku tertentu, (kontrol perilaku yang rendah) seorang individu tidak akan memiliki intensi (minat) yang kuat untuk melaksanakan perilaku tersebut (Engel, Blackwell, dan Miniard, 1995). (4) Intensi (Minat) Menurut Fishbein dan Ajzen (1975), intensi (minat) merupakan komponen yang ada dalam diri seorang individu yang mengacu pada keinginan untuk melakukan suatu tingkah laku atau perilaku tertentu. Intensi didefinisikan sebagai dimensi probabilitas subjektif seorang individu berkaitan dengan antara diri individu dan perilaku. Bandura (1986), menyatakan bahwa intensi (minat) merupakan suatu kebulatan tekad untuk melakukan suatu aktivitas/perilaku tertentu atau menghasilkan suatu keadaan tertentu di masa yang akan datang. Intensi menurutnya adalah bagian vital dari Self regulation individu yang dilatarbelakangi oleh motivasi seseorang untuk bertindak. Keinginan berperilaku (behavioral intention) adalah suatu proposisi yang menghubungkan diri dengan tindakan/perilaku yang akan datang. Lahirnya keputusan dari seseorang untuk melakukan sesuatu juga dapat diakibatkan dari stimulus yang dirasakannya pada saat pra pengambilan keputusan stimulus tersebut diantaranya adalah kemanfaatan yang pada tahap awal menstimulus sikap dan intensi (F.Latief \& D.Dirga, 2020)

Berdasar pada uraian diatas maka penelitian ini disusun melalui konsep kerangka pemikiran yang dapat digambarkan sebagi berikut :

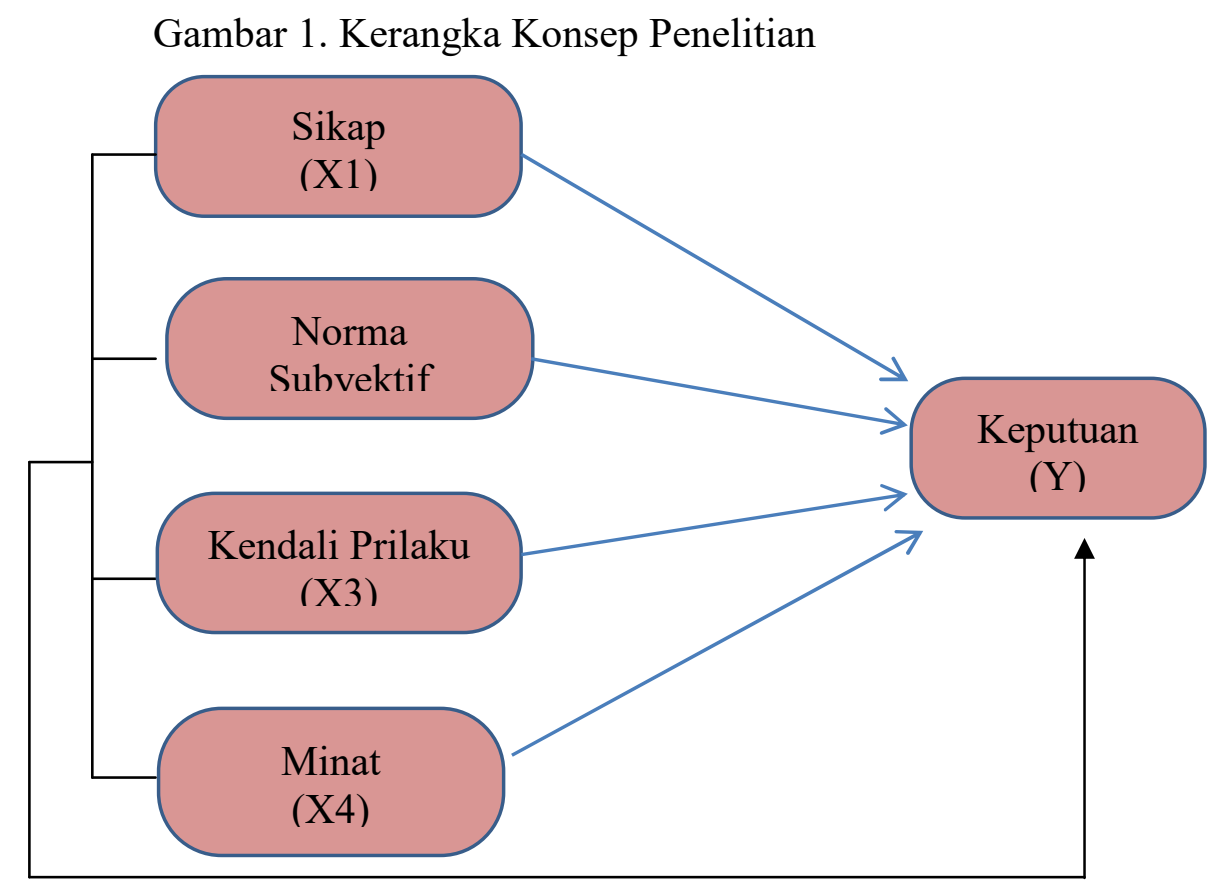

Melalui gambar kerangka konsep di atas maka akan terdapat empat hipotesis yang dikembangkan dalam penelitian ini yaitu

1. Sikap, Norma , kendali dan minat berpengaruh secara parsial tehadap keputusan 
mahasiswa dalam memilih prodi pada Perguruan Tinggi

2.Sikap, Norma, Kendali dan Minat berpengaruh secara simultan terhadap keputusan mahasiswa dalam memilih prodi pada perguruan tinggi

\section{METODE PENELITIAN}

Penelitian ini menggunakan pendekatan penelitian asosiatif. Peneltian asosiatif merupakan suatu penelitian yang mencari hubungan atau pengaruh antara satu variabel dengan variabel yang lain (Sugiyono, 1994:4). Penelitian ini dilaksanakan di STIMLAS Jaya Makassar. Waktu pelaksanaan penelitian ini dilaksanakan pada Januari - Maret 2020.denhan sampel penelitian sebanyak 69 (enam puluh Sembilan) orang yang merupakan Mahasiswa angkatan 2019-2020

Teknik analisis data menggunakan analisa regresi linier berganda yang didahului dengan uji validitas dan uji reliabiitas terhadap data penelitian uji hipotesis digunakan uji t untuk menguji hubungan seara parsial dan uji f untuk mengetahui hubungan secara simultan. Analisis kebermaknaan dalam penelitian ini digunakan melalui uji koefisien determinasi (R square)

\section{HASIL PENELITIAN DAN PEMBAHASAN}

\section{Hasil}

Perhitungan statistik dalam analisis regresi linier berganda yang digunakan dalam penelitian ini adalah dengan menggunakan bantuan program komputer IBM SPSS for Windows versi 23. Hasil pengolahan data dengan menggunakan program SPSS selengkapnya ada pada lampiran dan selanjutnya dijelaskan pada Tabel 5.14 berikut ini :

Tabel 1 Hasil Analisis Regresi Linier Berganda

\begin{tabular}{|c|c|c|c|c|c|}
\hline \multirow[b]{2}{*}{ Model } & \multicolumn{2}{|c|}{$\begin{array}{l}\text { Unstandardized } \\
\text { Coefficients }\end{array}$} & \multirow{2}{*}{$\begin{array}{c}\text { Standardized } \\
\text { Coefficients } \\
\text { Beta }\end{array}$} & \multirow[b]{2}{*}{$\mathrm{t}$} & \multirow[b]{2}{*}{ Sig. } \\
\hline & B & $\begin{array}{l}\text { Std. } \\
\text { Error }\end{array}$ & & & \\
\hline 1 (Constant) & -.616 & .290 & & -2.120 & .038 \\
\hline Sikap & .634 & .068 & .474 & 9.336 & .000 \\
\hline Norma & .327 & .048 & .312 & 6.816 & .000 \\
\hline Kendali & .048 & .024 & .048 & 1.979 & .052 \\
\hline Minat & .183 & .038 & .187 & 4.785 & .000 \\
\hline
\end{tabular}

a. Dependent Variable: Keputusan

Model persamaan regresi yang dapat dituliskan dari hasil tersebut dalam bentuk persamaan regresi sebagai berikut :

$$
\mathrm{Y}=-0,616+0,634 \mathrm{X} 1+0,327 \mathrm{X} 2+0,048 \mathrm{X} 3+0,183 \mathrm{X} 4
$$

Persamaan regresi tersebut dapat dejelaskan sebagai berikut :

a. Konstanta sebesar -616 memiliki arti jika variabel X1, X2, X3 Dn X4 tidak terdapat perubahan maka nilai Keputusan -0,616

b. Koefisien regresi variabel sikap mempunyai arah positif dalam pengaruhnya terhadap Keputusan memilih Program Studi Nilai koefisien sebesar 0,634 
mengindikasikan bahwa jika terjadi peningkatan senilai satu satuan dalam variabel X1 maka Y atau keputusan mahasiswa dalam memilih prodi akan bertambah sebesar 0,634

c. Koefisien regresi variabel Norma mempunyai arah positif dalam pengaruhnya terhadap Keputusan Mahassiswa dalam memilih prodi. Nilai koefisien sebesar 0,327 mengindikasikan bahwa jika terjadi peningkatan senilai satu satuan dalam variabel X2 maka Y atau keputusan Mahasiswa dalam memilih prodi akan bertambah sebesar 0,327

d. Koefisien regresi variabel Kendali mempunyai arah positif dalam pengaruhnya terhadap Keputusan Mahassiswa dalam memilih prodi. Nilai koefisien sebesar 0,048 mengindikasikan bahwa jika terjadi peningkatan senilai satu satuan dalam variabel X3 maka Y atau Keputusan Mahassiswa dalam memilih prodi akan bertambah sebesar 0,211

e. Koefisien regresi variabel Minat mempunyai arah positif dalam pengaruhnya terhadap Keputusan Mahassiswa dalam memilih prodi. Nilai koefisien sebesar 0,183 mengindikasikan bahwa jika terjadi peningkatan senilai satu satuan dalam variabel X4 maka $\mathrm{Y}$ atau Keputusan Mahassiswa dalam memilih prodi akan bertambah sebesar 0,183

\section{Pengujian hipotesis secara parsial}

\section{Pengaruh Sikap Terhadap Keputusan Mahasiswa Dalam memilih Program Studi}

Hasil pengujian diperoleh nilai $\mathrm{t}$ untuk variabel Sikap menunjukkan nilai $\mathrm{t}=$ 9,336 sedangkan nilai t tabel untuk n 69 adalah sebesar 1,9949 dengan demikian nilai $t$ hitung lebih besar dari nilai t tabel sehingga terbukti bahwa terdapat pengaruh antara variabel Sikap dengan Keputusan Mahasiswa dalam memilih program studi, dengan nilai signifikansi sebesar 0,000< 0,05 . Dengan nilai signifikansi di bawah 0,05 tersebut menunjukkan bahwa Sikap memiliki pengaruh yang signifikan terhadap Keputusan Mahasiswa dalam memilih program studi.

2. Pengaruh Norma Terhadap Keputusan Mahasiswa Dalam memilih Program Studi

Hasil pengujian diperoleh nilai $\mathrm{t}$ untuk variabel Sikap menunjukkan nilai $\mathrm{t}=$ 6,816 sedangkan nilai t tabel untuk n 69 adalah sebesar 1,9949 dengan demikian nilai $t$ hitung lebih besar dari nilai t tabel sehingga terbukti bahwa terdapat pengaruh antara variabel Norma dengan Keputusan Mahasiswa dalam memilih program studi, dengan nilai signifikansi sebesar $0,000<$ 0,05 . Dengan nilai signifikansi di bawah 0,05 tersebut menunjukkan bahwa Norma memiliki pengaruh yang signifikan terhadap Keputusan Mahasiswa dalam memilih program studi

3. Pengaruh Kendali Terhadap Keputusan Mahasiswa Dalam memilih Program Studi

Hasil pengujian diperoleh nilai t untuk variabel Kendali menunjukkan nilai t $=1,979$ sedangkan nilai t tabel untuk n 69 adalah sebesar 1,9949 dengan demikian nilai $t$ hitung lebih kecil dari nilai t tabel sehingga tidak terbukti terdapat pengaruh antara variabel Sikap dengan Keputusan Mahasiswa 


\section{AkMen}

Volume 17 Nomor 2 Juni 2020

Hal.173-182

e-ISSN : 2621-4377 \& p-ISSN : 1829-8524

Hbmepage: https//e-jurnal.stienobel-indonesiaacid/index.php/akmen

dalam memilih program studi, dengan nilai signifikansi sebesar 0,0520 > 0,05. Dengan nilai signifikansi di atas 0,05 tersebut menunjukkan bahwa Kendali tidak memiliki pengaruh yang signifikan terhadap Keputusan Mahasiswa dalam memilih program studi

4. Pengaruh Minat Terhadap Keputusan Mahasiswa Dalam memilih Program Studi

Hasil pengujian diperoleh nilai $\mathrm{t}$ untuk variabel Minat menunjukkan nilai $\mathrm{t}=$ 4,785 sedangkan nilai t tabel untuk n 69 adalah sebesar 1,9949 dengan demikian nilai t hitung lebih besar dari nilai t tabel sehingga terbukti bahwa terdapat pengaruh antara variabel Minat dengan Keputusan Mahasiswa dalam memilih program studi, dengan nilai signifikansi sebesar $0,000<$ 0,05. Dengan nilai signifikansi di bawah 0,05 tersebut menunjukkan bahwa Minat memiliki pengaruh yang signifikan terhadap Keputusan Mahasiswa dalam memilih program studi

\section{Uji F (Pengujian Hipotesisi Secara Simultan)}

Uji F dimaksudkan untuk mengetahui apakah variabel independent dalam hal ini adalah variable Sikap, variabel Norma, variabel Kendali dan Variabel Minat berpengaruh secara bersama sama terhadap Keputusan mahasiswa dalam memilih Program Studi. Hasil perhitungan uji F untuk menguji hubungan variabel indpenden secara bersama-sama diperoleh pada Tabel 4.13 berikut ini :

Tabel 5.15 Hasil Analisis Regresi Secara bersama-sama

\begin{tabular}{|c|c|c|c|c|c|}
\hline \multicolumn{6}{|c|}{ ANOVA $^{a}$} \\
\hline Model & $\begin{array}{l}\text { Sum of } \\
\text { Squares }\end{array}$ & $\mathrm{df}$ & Mean Square & $\mathrm{F}$ & Sig. \\
\hline $\begin{array}{ll}1 & \text { Regressio } \\
\mathrm{n}\end{array}$ & 232.138 & 4 & 58.034 & 1359.613 & $.000^{\mathrm{b}}$ \\
\hline Residual & 2.732 & 64 & .043 & & \\
\hline Total & 234.870 & 68 & & & \\
\hline
\end{tabular}

a. Dependent Variable: Perilaku

b. Predictors: (Constant), Minat, Kendali, Norma, Sikap

Dari hasil pengolahan statistik di atas menunjukkan nilai $\mathrm{F}$ hitung = 1359,613 sedangkan $\mathrm{F}$ tabel untuk $\mathrm{n} 69$ dengan $\mathrm{df1}=\mathrm{k}-1=4$ dimana $\mathrm{k}$ adalah jumlah seluruh variabel ( 5 variabel) dikurang dengan variabel dependent (1 variabel) dan df $2=\mathrm{n}-\mathrm{k}=64$ dimana $\mathrm{n}$ adalah sebanyak 69 dikurang dengan $\mathrm{k}$ (5) adalah pada titik nilai $\mathrm{F}$ tabel sebesar 2,52 hasil ini menunjukkan nilai $\mathrm{F}$ hitung lebih besar dari nilai $\mathrm{F}$ tabel untuk itu dapat disimpulkan bahwa terdapat pengaruh antara variabel-variabel $\mathrm{X}$ secara bersama-sama terhadap variabel $\mathrm{Y}$ (keputusan Mahasiswa).

Nilai signifikansi sebesar $0,000<0,05$. Dengan nilai signifikansi di bawah 0,05 menunjukkan bahwa secara bersama-sama sikap, norma, kendali dan minat mempunyai pengaruh yang positif dan signifikan terhadap keputusan Mahasiswa dalam memilih Program Studi 


\section{Koefisien Determinasi}

Koefisien determinasi ini digunakan untuk mengetahui seberapa besar pengaruh variabel-variabel bebas memiliki pengaruh terhadap variabel terikatnya. Nilai koefisien determinasi ditentukan dengan nilai $R$ square

Tabel 5.16 Koefisien Determinasi

Model Summary ${ }^{b}$

\begin{tabular}{ll|r|r|} 
Model & R & R Square & \multicolumn{2}{|c}{$\begin{array}{c}\text { Adjusted R } \\
\text { Square }\end{array}$} \\
\hline 1 & $.994^{\mathrm{a}}$ & .988 & .988 \\
\hline
\end{tabular}

Hasil perhitungan regresi dapat diketahui bahwa koefisien determinasi R.Square yang diperoleh sebesar 0,994. Hal ini berarti 99,4\% Keputusan Mahasiswa dalammemilih program studi dipengaruhi oleh sikap, norma,kendali dan minat sedangkan sisanya yaitu $0,6 \%$ keputusan mahasiswa dalam memilih program studi dipengaruhi oleh variabel-variabel lainnya yang tidak diteliti dalam penelitian ini.

\section{Pembahasan}

Hasil penelitian ini menunjukkan tiga variabel $X$ yaitu Sikap Norma dan Minat berpengaruh secara positif dan signifikan terhadap keputusan mahasiswa untuk memilih program studi pada perguruan tinggi sementara satu variabel $\mathrm{x}$ yaitu Kendali berpengaruh positif tetapi tidak signifikan terhadap keputusan Mahasiswa dalam memilih program studi pada perguruan tinggi.

Penelusuran lanjutan terkait hasil penelitian ini yang menunjukkan bahwa sikap memiliki pengaruh dalam keputusan hal ini diperkuat bahwa sikap merupakan bentuk dari ketetapan atau perasaan seseorang yang memiliki andil besar bagi seseorang untuk melakukan sesuatu atau tidak melakukan sesuatu. Hal ini sesuai dengan teori yang dikemukakan oleh Rifai dan Mulyadi (2012) begitupula dengan Norma yang merupakan nilai yang mendorong keinginan seseorang untuk memiliki suatu obyek tertentu hal ini juga terlihat mahasiswa dalam mennentukan pilihan sangat terkait dengan nilainilai tersebut.

Sedangkan minat adalah Sesutu yang memang sudah tertanam dalam diri seseorang yang merupakan kecenderungan yang memberikan rasa nyaman untuk melakukan atau mendapatkan sesuatu dan hal ini pulalah yang mendorong mahasiswa untuk menentukan keputusan. Sementara faktor kendali perilaku memang menjadi suatu pertimbangan seperti yang dikemukakan oleh Ajzen (2005) namun kecenderungan mahasiswa menempertimbangkan saran dan pendapat seseorang dalam memutuskan tetap menjadi pertimbangan tetapi tidak sekuat pertimbangan yang datang dari diri sendiri yaitu sikap, Norma dan Minat

\section{Kesimpulan}

Penelitian ini menyimpulkan bahwa pengambilan keputusan diawali dengan pertimbangan yang masak terutama pertimbangan yang mempengaruhi pribadi seseorang dari dalam dirinya yaitu sikap, norma,kendali dan minat. Dengan demikian 
terbukti bahwa Sikap, Norma, Kendali danminat berpengaruh terhadap keputusan mahasiswa dalam memilih program studi pada Perguruan Tinggi. untuk itu secara aplikatif dalam konteks manajemen pemasaran menjadi sangat penting bagi Perguruan Tinggi untuk memperhatikan permasalahan pendorong perilaku masyarakat dalam hal ini calon Mahasiswa, sehingga akan didapatkan pendekatan dan strategi yang tepat dalam menarik calon Mahasiswa dalam memilih Program Studi yang ditawarkan kepada masyarakat.

\section{DAFTAR PUSTAKA}

Ajzen, I \& Fishbein, M., 2012. Belief, Attitude, Intention and Behavior: An Introduction to Theory and Research.Reading, MA: Addison-Wesley

Ajzen, I. 2006. Behavioral Interventions Based on the Theory of Planned Behavior. Retrieved July 4, 2006 from http ://www-unix.oit. Umass .edu/ aizen/

Ajzen, I. 1985. From intentions to actions: A theory of planned behavior. In J. Kuhl \& J. Beckmann (Eds.), Action control: From cognition to behavior". New York: Springer-Verlag. pp. 11-39.

Ajzen, I., 1991, The Theory Of Planned Behavior. Organizational Behavior and Human Decision Processes, 50(1): hal. 179-211. Aksara.

Alleyne, P and K. Phillips. 2011. Exploring Academic Dishonesty Among University Students in Barbados: An Estension to the Theory of Planned Behavior. J. Acad Ethics (9), 323-338. Springers Science, Business Media B.V 2011.

Bawantara, Agung. 2007. Lulus SMA Kuliah Dimana? Panduan Memilih Program Studi. Jakarta: PT. Kawan Pustaka.

Beck, L., \& Ajzen, I. 1991. Predicting Dishonest Actions Using The Theory Of Planned Behavior. Journal of Research in Personality, 25, 285- 301

Champoux, Josefh,E.,Thompson-SW, 2003. Oraganizational Behavior. Essential Tenets

Dharmmesta, Basu Swastha dan Handoko, Hani. 2003. Manajemen Pemasaran: Analisis Perilaku Konsumen.: BPFE. Yogyakarta.

Dimitriades. 2006. Zoe S. Customer satisfaction, loyalty and commitment in service organizations. Management Research News. Vol. 29 No. 12, pp. 782-800.

Engel, Blackwell, dan Miniard. 1995. Perilaku Konsumen.: Binarupa, Jakarta Barat

Fathinah, Zaki Baridwan. 2013. Determinat Minat Individu dan Pengaruhnya terhadap Perilaku Penggunaan Sistem Informasi Berbasis Teknologi di Bank Syariah. Skripsi. Universitas Brawijaya.

Hartono, Andry. 2006. Terapi Gizi dan Diet Rumah sakit. Penerbit Buku Kedokteran EGC Jakarta 
Hamalik, Oemar. 2004. Proses Belajar Mengajar. Bumi Aksara. Jakarta.

Hartono, J.M. 2007. Sistem Informasi keperilakuan. Yogyakarta.

Hartono, Jogiyanto. 2013. Metodologi Penelitian Bisnis Salah Kaprah dan Pengalaman-pengalaman. Edisi 5. BPFE-Yogyakarta.

Hogg \& Vaughan. 2011. Social Psychology 6th ed. London: Prentice Hall.

JacquelineLiza Fernandez Fernandez. 2010. An explanatory study of faktors influencing the decision of students to study at universiti sains Malaysia dalam Jurnal Kajian Malaysia, Vol. 28, No. 2

Jin, Liauw She dan Mas'ud Machfoedz. 1998. Faktor-faktor yang Mempengaruhi Praktik Perataan Laba Pada Perusahaan yang Terdaftar di Bursa Efek Jakartall. Jurnal Riset Akuntansi Indonesia. Vol. 1(2)

Joseph Kee Ming Sia.2011. Post Secondary Student'Behaviour in the College Choice Decision . Journal of Marketing Research \& Case Studies Curtin University

Latief, F., \& Dirwan, D. (2020). PENGARUH KEMUDAHAN, PROMOSI, DAN KEMANFAATAN TERHADAP KEPUTUSAN PENGGUNAAN UANG DIGITAL. Jurnal Ilmiah Akuntansi Manajemen, 3(1), 16-30.

Loudon, David L \& Albert J. Della Bitta. 1993. Consumer Behaviour: Concepts and Applications (4th Edition). New York: Mc. Graw Hill, Inc.

Mas'ud, H. Muchlis, 2012. Pengaruh Sikap, Norma-norma Subyektif dan Kontrol Perilaku yang Dipersepsikan Nasabah Bank terhadap Keinginan untuk Menggunakan ATM Bank BCA di Kota Malang, Jurnal Manajemen dan Akuntansi, Vol. 1, No. 3, Desember 2012.

Michener, H. A., DeLamater, J. D. and Myers, D. J. 2004, Social Psychology (Australia: Thompson Wadsworth), (Fifth Edition).

Mcleod, Raymond. 2008. Sistem Informasi Manajemen Edisi 10. Jakarta: Salemba Empat

Mulyatini, Sri., Suharyati., Tati Handayani . 2013 .Faktor-Faktor yang Berpengaruh Terhadap Keputusan Memilih Program Studi. Jurnal JP.feb Unosed Vol 3, No 1: Proceeding Seminar Nasional \& Call For Papers (SCA-3)

Peter dan Olson, 1996. Perilaku Konsumen dan Strategi Pemasaran. Gelora Aksara Pratama. Jakarta

Rivai, Veithzal dan Mulyadi, Deddy,. 2012. Kepemimpinan dan Perilaku Organisasi. Raja Grafindo Persada. Edisi Ketiga. Jakarta.

Rivai, Veithzal, 2009. Manajemen Sumber Daya Manusia Untuk Perusahaan. Raja Grafindo Persada, Jakarta.

Stephen P. Robbins, 1996.Perilaku Organisasi, Konsep, Kontroversi danAplikasi. Alih Bahasa : Hadyana Pujaatmaka. Edisi Keenam. Penerbit PT.Bhuana Ilmu Populer, Jakarta. 
Sawaji, Jamaluddin., Djabir Hamzah, Idrus Taba. 2011. Pengambilan Keputusan Mahasiswa Dalam Memilih Perguruan Tinggi” Swasta di Sulawesi Selatan . Jurnal Pasca Unhas

Sugiyono 2001, Metode Penelitian Administrasi, Penerbit Alfabeta Bandung

Supomo, Bambang \& Indriantoro, Nur. 2002, Metodologi Penelitian Bisnis, Cetakan Kedua, Penerbit BFEE UGM.Yogyakarta

Tan et al. 2007. Intellectual capital and financial returns of companies. Journal of Intellectual Capital Vol. 8 No. 1, 2007 pp. 76-95.

Whitley, J., B.E. and P. Keith-Spiegel. 2002. Academic Dishonesty: An Educator's Guide. Mahwah, NJ, Lawrence Erlbaum Associates.

Wijaya, Tony. 2009. Analisis Structural Equation Modeling Menggunakan AMOS.Universitas Atma Jaya Yogyakarta.Yogyakarta

Zakarija, Achmat. 2010. Theory of Planned Behavior, Masihkah Relevan?. http://zakarija.staff.umm.ac.id/files/2013/12/,diakses 20 November 2015 